\title{
外傷性クモ膜下出血後の感音難聴症例
}

\author{
宗田 由美・大谷 巌・大㭇 好正*
}

\section{A Case of Sensorineural Hearing Loss after Traumatic Subarachnoid Hemorrhage}

\author{
Yumi Sota and Iwao Ohtani \\ (Fukushima Medical College) \\ Kohsei Ohtsuki \\ (Hoshi General Hospital)
}

Sensorineural hearing loss, tinnitis, vertigo or dizziness sometimes occur following subarachnoid hemorrahge ( $\mathrm{SAH}$ ), although clinical case reports are extremely rare due to severe consciousness loss or other brain symptoms following $\mathrm{SAH}$.

A 51-year-old man complained of poor bilateral hearing after losing consciousness for 5 minutes after a head trauma. Clinical examinations revealed bilateral sensorineural hearing loss without temporal bone fracture or brain stem injury but with SAH in the bilateral Silvius fissure. From neuro-otological findings it was thought that sensorineural hearing loss was caused by damage to the inner ear or the brain stem area due to hemorrhage or force.

Key words: traumatic subarachnoid hemorrhage, sensorineural hearing loss, neurootological findings

はじめに

クモ膜下出血 (以下 SAH) 後に難聴, 耳鳴, 眩 量等の症状が出現することは知られており，そ の機序については側頭骨を用いた病理組織学的 検討1) 3) 等がなされているが，臨床的な報告例 は極めて稀である。その理由の一つには SAH では意識障害等の中枢神経症状の合併が多く, 周囲とのコミュニケーションができない状態に 長くおかれることも少なくないために，詳細な 神経耳科学的所見を把握できないことが考劣ら
れる。一方で予後の良好な症例では内耳にまで 重篤な症状を来さない2)こともその理由と考党 られている。

今回われわれは外傷性 SAH 後に両側の感音 難聴を認めた一症例を経験したので，若干の文 献的考察を加兄報告する.

\section{症例}

患者 : 51歳, 男性.

主訴 : 両側難聴(特に右難聴) と耳鳴, 軽度の ふらつき。 
家族歴および既往歴：特記すべさ所見はない， 現病歴: 平成 4 年 2 月 29 日, 歩行中にスクー ターと接触し，転倒した際に頭部を打撲。この 時約 5 分間の意識消失があり，近医に搬送され る. 頭部 CTにて両側シルビウス裂に SAH(図 1) をまた MRI にて右前頭部に脳挫傷と考党ら れる所見を認めた。

その他の部位には外傷や骨折はなく, 開頭手 術を行わず，保存的療法にて受傷後 7 日目頃か ら頭部 CT 所見の改善傾向が見られた。しかし 意識回復直後より両耳(特に右耳)の難聴と耳鳥 および軽度のふらつきを訴え，改善しないため に精查を目的に平成 4 年 3 月 18 日, 星総合病院 耳鼻咽喉科に紹介となった。

検査所見：両鼓膜は正常で鼻咽喉頭に異常は 見られなかった。純音聴力検査で右耳は平均聴 カレベル $73.8 \mathrm{~dB}$ の高音漸傾型の感音難聴, 左

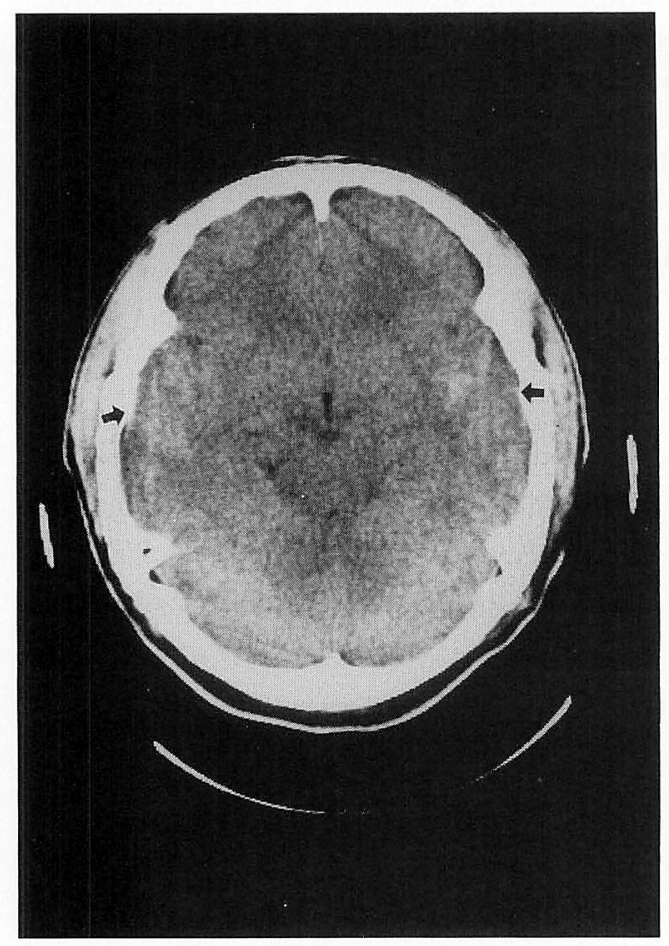

図 1 受傷時頭部 CT 所見

両側のンルビウス裂にクモ膜下出血と考えられる LDA (๒) を認める。
耳は $38.8 \mathrm{~dB}$ の水平型感音難聴を認めた (図 2 ). 耳レントゲンおよび側頭骨 CT 検査では骨折, 中耳炎，腫瘍等を疑ら所見は見られず(図 3 ), MRI 検査でも内耳拈よび脳幹部付近に明らか な損傷を疑う所見は認められなかった(図 4). ティンパノメトリーは両側 $\mathrm{A}$ 型で耳小骨筋反射 は両耳ともに認められた。内耳機能検査では自 記オージオメトリーにて両耳とも Jerger の II 型を呈し，SISI 検査では両耳ともにリクルー トメント現象陽性であった。平衡機能検査では

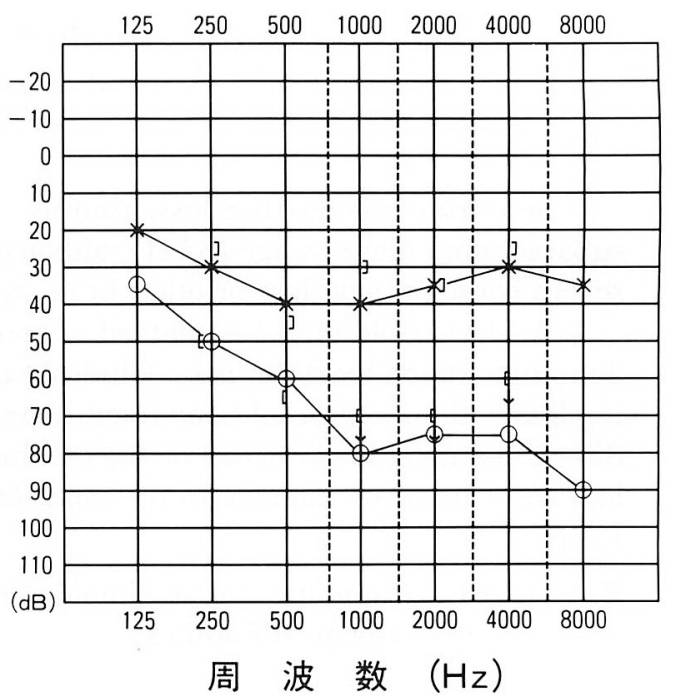

図 2 標準純音聴力検査所見

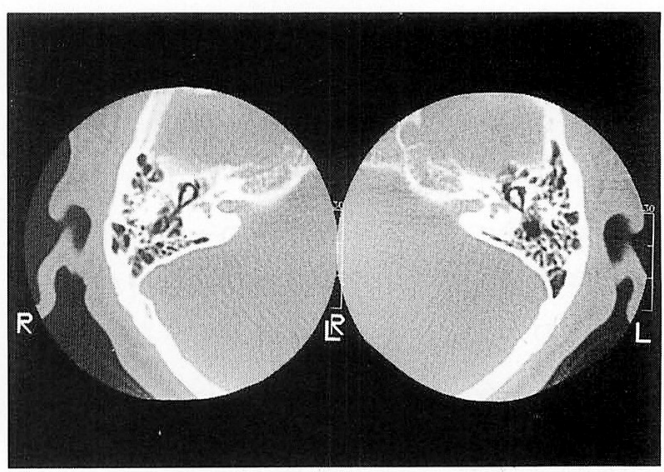

図 3 初㡎時側頭骨 CT 所見 
非注視時と頭位変換時に左向きの水平性眼振が 見られたが温度眼振検査では半規管麻痺は認め られなかった(表 1).ABR 検査では右耳は 100 $\mathrm{dB}$ の刺激にのみ I, III, V波を認め, III波, V波ともに潜時が延長していた. 左耳は $50 \mathrm{~dB}$ の刺激にまで反応を認めたが，恧波，V波とも に軽度の潜時延長を認めた(図 5 ).

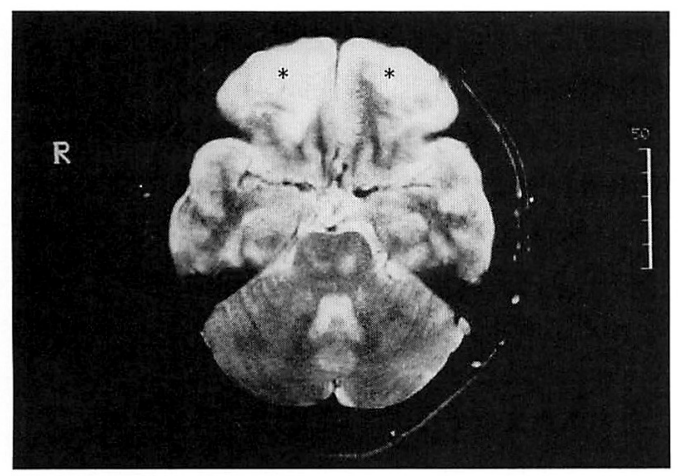

図 4 MRI 所見

脳幹部に異常を認めず．前頭葉に脳挫傷を疑う所

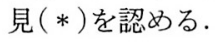

表 1 その他の検査所見

\begin{tabular}{|c|c|c|}
\hline \multicolumn{3}{|l|}{ 1.内耳機能検査 } \\
\hline \multirow[t]{3}{*}{ ・自記オージオメトリー } & : 右耳 & $\begin{array}{l}\text { Jerger II 型 } \\
\text { (内耳性蓶聴に見られる型) }\end{array}$ \\
\hline & 左耳 & Jerger II 型 \\
\hline & & 同上 \\
\hline \multirow[t]{2}{*}{ - SISI検査 } & : 右耳 & $\begin{array}{l}1 \mathrm{kHz}, 4 \mathrm{kHz} 100 \% \\
\text { (リクルートメント現象陽性) }\end{array}$ \\
\hline & 左耳 & $1 \mathrm{kHz}, 4 \mathrm{kHz} \quad 85 \%$ \\
\hline
\end{tabular}

2. $\mathrm{ABR}$ (㮦性脳幹反応) 検查

同上

右耳 $100 \mathrm{~dB}$ の刺激にのみ I, III, V波を認め, 红波、V波は潜 時の延長を認めた。

左耳50dBの刺激にまで $\mathrm{I}, \mathbb{I I}, \mathrm{V}$ 波を認め, 纮, V波は軽 度潜時の延長を認めた。
3.チンパノメトリー：右耳 A型
左耳 A型
4.耳小骨筋反射 : 右耳 陽性
左耳 陽性
5. 平衡機能検查
- 非注視眼振榙查：左向きの水平性眼振を認める。
-頭位变換眼振検查：左向きの水平性眼振を認める。
- 温度眼振検查 : 半規管麻㾝 $(-)$

治療および経過：副腎皮質ホルモン剂，ビタ ミン剂, 脳循環改善剂, 脳代謝賦活剂を用い, ふらつきは発症から約 1 力月で消失し, 約 2 力 月後には SAH および脳挫傷所見の改善が認め られた。しかし難聴, 耳鳴の改善は現在まで多 られていない。

\section{考察}

SAH による耳症状の発症の要因としては頭 蓋内圧の急激な上昇によるもの价 -6) やク膜下 腔から内耳に侵入した血液成分によるもの1) 3) などが考兄れている. Allen ら4) は頭蓋内圧の 急激な上昇は聴覚に可逆的な变化をもたらすと 報告している.また Holden ${ }^{1)}$ は内耳内の大量の 血液は内耳液の物理的, 生理的な変化をもたら し, 結果的に感覚細胞の変性を引き起こすので はないかと推察している. Arnold と Vosteen ${ }^{7)}$

\section{ABR所見}

〈右 耳〉
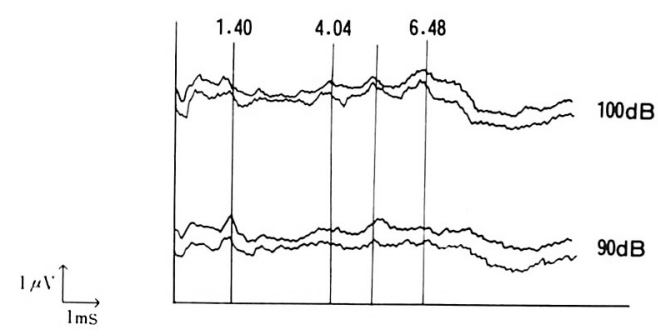

〈左 耳〉

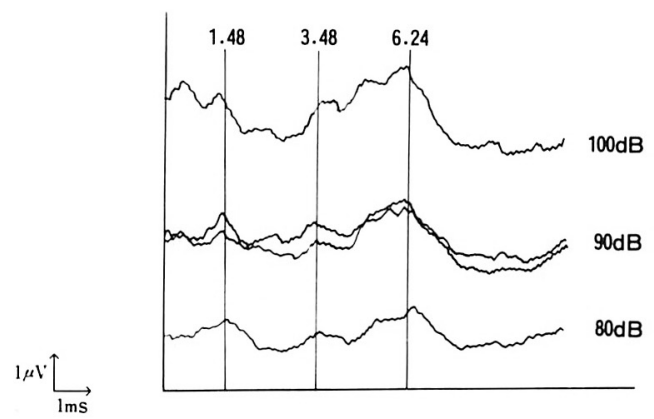

図 5 ABR 所見 $(4000 \mathrm{~Hz})$ 
は1977年に SAH に突発難聴様の感音難聴を発 症した一例を報告しているが側頭骨所見として 内耳内に大量の血液が侵入していたことを呈示 している.内耳内に侵入した血液が感覚細胞に 何らかの障害を与え, 症状として発現するには ある程度の出血量が必要と考兄られ，例觉ばア ブミ骨手術の際などに血液が外リンパに混入し ても聴力には影響を及ぼさないとする報告8)も ある. 従って SAH 時に何らかの内耳の障害や 症状があったとしてもそのような症例は重症例 である可能性が強く, 症状の把握が困難であっ たり，症状を訴少る以前に死亡してしまう場合 が多いのではないかと考えられていた。

本症例は外傷による SAH ではあるが高度な 出血や骨折，脳実質の広範な損傷を伴わない軽 傷例で意識消失時間も5 分間といら短いもので あったにもかかわらず，受傷後より中等度の感 音難聴が認められた。内耳機能検査では内耳性 難聴を示唆する所見が得られ，ABR 検査所見 からは蝸牛神経や下部脳幹付近の障害9)が考兄 られた。しかし CT, MRIを用いた画像診断か らは内耳, 内耳道および脳幹部付近の明らかな 骨折や損傷は認められなかった.

本症例では顔面神経麻痺等の他の脳神経症状 を伴わず，このことは顔面神経が蝸牛神経に比 して障害を受けにくいことを示唆する所見と考 えられた。また脳幹レベルに限局した障害を想 定した場合，選択的に蝸牛神経核のみ障害され たとしなくてはならないが，外傷に拈いては実 際に選択的に障害される可能性は低いと考兄ら れる。また迷路振盪に伴う感音難聴では薬物療 法により受傷後約 1 力月位で改善傾向が見られ る症例が多い10) のに反して, 本症例の聴力予 後は不良であった，本症例は生存して括り病理 組織学的診断を欠くために障害部位の診断につ いては推測の域を出ないが，画像診断では確認 されないような何らかの損傷があったと仮定し た場合，神経耳科学的所見や外傷性であること を考慮に入れると障害部位は内耳から蝸牛神経, 下部脳幹付近までの範囲ではないかと推察され
た. その原因としては受傷時の外力による迷路 振盪, 出血による頭蓋内圧の急激な上昇, 血液 成分の内耳道や蝸牛水管侵入などの複数の要因 が，内耳の感覚細胞や蝸牛神経あるいは脳幹部 に何らかの障害を及ぼしたのではないかと考え られた。

\section{まとめ}

外傷性クモ膜下出血後に感音難聴を認めた症 例を報告した。本症例に抢ける障害部位は内耳 から蝸牛神経, 下部脳幹部にいたる範囲と推定 された。クモ膜下出血に伴ら聴力障害, 耳鳴の 臨床報告例は少なく，その発症機序については さらに検討を要するものと考えられるが今後も 症例を重ね, 神経耳科学診断を進めて行く必要 があると思われる。

な扮本論文の要旨は第 2 回日本耳科学会臨床学会 に招いて発表した。

\section{参考文献}

1) Holden HB and Schuknecht HF : Distribution pattern of blood in the inner ear following spontaneous subarachnoid hemorrhage. J Laryngol $82: 321 \sim 329,1968$.

2）宗田由美, 相川 通: クモ膜下出血症例の側頭 骨病理組織学的検討. 耳鼻臨床 補 $43: 13 \sim 28$, 1991.

3）安斎友博, 大谷 㦑, 相川 通, 他: クモ膜下 出血 3 症例の側頭骨病理所見. Ear Res Jpn $17: 401 \sim 402,1986$.

4) Allen GW and Habibi M : The effect of increasing the cerebrospinal fluid pressure upon the cochlear microphonics. Laryngoscope 72 : 423 434, 1962.

5）深谷 卓, 阿部和也, 野原利江: 脳脊髄圧变化 によるABR の変化. Audiology Japan 27 : 673 $\sim 674,1984$.

6）吉田雅文, 君村 隆, 上村卓也 : 脳沗䯣圧変化 の内耳圧とマイクロホン電位に及ぼす影響.

Ear Res Jpn 18 : 49 52, 1987.

7) Arnold $\mathrm{W}$ und Vosteen $\mathrm{KH}$ : Akute Ertaubung als Folge der Ruptur eines Basilarisaneurysma. HNO $25: 127 \sim 130,1977$. 
8) Linthicum FH and Sheehy JL : Blood in the vestibule at stapedectomy human case report with histological findings. Ann Otol 78 : 425 429, 1969.

9）船井洋光: ABR の起源と局在診断の可能性. JOHNS 5 : 24〜30, 1989.
10）森 弘：外傷性顔面神経麻瘏. JOHNS 3： 87 90, 1987.

$\left(\begin{array}{l}\text { 別刷請求先 : 宗田由美 } \\ \text { T } 960-12 \text { 福島市光が丘 } 1 \\ \text { 福島県立医科大学耳鼻咽嗼科学教室 }\end{array}\right)$ 